\title{
The Morphological Processes of Noun Forming Derivational Affixes in Dickens' A Christmas Carol
}

\author{
Ni Made Indriyana Savitri ${ }^{1 *}$, Ni Made Ayu Widiastuti ${ }^{2}$ \\ English Department, Faculty of Arts, Udayana University \\ ${ }^{1}$ [Email:indriyanasavitri@gmail.com], ${ }^{2}$ [Email:ayufsb@gmail.com], \\ *Corresponding Author
}

\begin{abstract}
This study entitled The Morphological Processes of Noun Forming Derivational Affixes in Dickens' A Christmas Carol aims to analyze the word class of base forms and derivational affixes forming nouns used in a fiction novel. The data were taken from the novel entitled A Christmas Carol written by Charles Dickens in 1843 by applying documentation method and note-taking techniques. The technique of analyzing data was done by classifying the derivational affixes forming nouns according to type of affixes and reducing the words containing derivational affixes that were similar. The data were analyzed by applying the theory of how new words are formed as derivations in morphology by Katamba (1993) as the main theory and the theory by Bauer (1983) as the supporting one. The findings showed that there were three classes of the base form used to produce new noun-based lexeme in the data, namely verb, adjective and noun. Types of affixes that were used were only suffixes, namely suffix-al, -er, -ar, -or, -ing, y, -ion, -ation, -ment, -ance, and-age which are attached to verb base, suffix-ity, -th, ness, and-ence which are attached to adjective base and suffix $-y$ which are attached to noun base.
\end{abstract}

Keywords: noun, morphological process, affixation, derivational affixes

\begin{abstract}
Abstrak
Penelitian ini bertujuan untuk menemukan kelas kata dari kata dasar dan imbuhan kata derivasi yang membentuk kata benda pada sebuah novel fiksi. Data diambil dari novel berjudul A Christmas Carol karya Charles Dickens pada tahun 1843 dengan mengaplikasikan metode dokumentasi dan teknik mencatat. Teknik menganalisis data dilakukan dalam dua langkah yaitu mengklasifikasi imbuhan kata derivasi yang membentuk kata benda sesuai dengan tipe-tipe imbuhan dan menghilangkan kata yang memiliki imbuhan yang sama. Data dianalisis dengan menggunakan teori tentang bagaimana kata baru terbentuk sebagai derivasi di morfologi yang dikemukakan oleh Katamba (1993) dan Bauer (1983). Hasil analisis menunjukkan bahwa ada tiga kelas kata yang digunakan untuk membentuk kata benda baru, yaitu kata kerja, kata sifat dan kata benda itu sendiri. Jenis imbuhan yang digunakan hanya berupa akhiran, yaitu akhiran-al, -er, -ar, -or, -ing, -y, -ion, -ation, -ment, -ance, dan-age ditambahkan pada kelas kata kerja, akhiran -ity, -th, -ness, dan-ence yang ditambahkan pada kelas kata sifat dan akhiran -y yang ditambahkan pada kelas kata benda.
\end{abstract}

Kata kunci: kata benda, proses morfologi, afiksasi, imbuhan derivasi 


\section{Background of the Study}

Morphology as a major level of linguistic analysis plays a considerable role in producing and building thousands of English words (Mhamad, 2013). English derives a huge number of words on a daily basis from all the languages of the world and morphology gives an idea about the source of the words with rules and regulations on how to form new words.

The word-formation processes in morphology can be done by affixation, conversion and compounding. There are two kinds of word-building in affixation namely inflectional process and derivational process. This study is concerned on the derivational process. Specifically, this study is focused on the derivational affixes which form nouns in the novel entitled A Christmas Carol written by Charles Dickens in 1843.

In analyzing noun forming derivational affixes, theories about how new words are formed as derivations in morphology proposed by Katamba (1993) and Bauer (1983) were applied. Futhermore, the meaning of new noun lexemes were based on the meaning of words in English Dictionary.

This study of defining the word formation may benefit people since it can enrich and widen the vocabulary. From a word class, people can make many new words in other word class by deriving the words. By attaching affixes to the base words, new words can be formed. That is why derivational process is important and interesting to be analyzed.

\section{Problems of the STudy}

a) What are the classes of the base form that are used in the morphological process in the novel A Christmas Carol?

b) What types of affixes are used in the morphological process in the novel $A$ Christmas Carol?

\section{Aims of the Study}

a) To identify and classify the classes of the base form that are used in the morphological process in the novel $A$ Christmas Carol.

b) To analyze and describe types of affixes that are used in the morphological process in the novel $A$ Christmas Carol.

\section{Research Method}

In making a scientific writing, a methodology is an important factor that should be used as a guide by researcher. There is a set of procedures in the systematic study that are applied within a discipline. Methodology consists of the data source, the method and technique of collecting data, method, and method and technique of analyzing data.

\subsection{Data Source}

The novel A Christmas Carol by Charles Dickens was used as the data source in this study. The original title of this novel is A Christmas Carol. In Prose. Being a Ghost Story of Christmas. It was published in 1843 by Chapman \& Hall in London. This novel was adapted for the stages, films and televisions. The novel was used as the data because there were many derivation processes found. This indicated many derived words found so it was relevant to the topic of this study.

\subsection{Method and Technique of Collecting Data}

Documentation method and notetaking techniques were used to collect the data in this study. The technique of collecting data in this study were done in two steps. First, reading the novel carefully. Second, taking note of words containing derivational affixes forming nouns. 


\subsection{Method and Technique of Analyzing Data}

The data were analyzed qualitatively in this study. Therefore, only the most relevant data were selected. The technique of analyzing data was done in two steps. First, classifying the derivational affixes forming nouns according to type of affixes. Second, reducing the derivational affixes forming nouns that were similar. The data analysis was based on theories about how new words are formed as derivations in morphology which was proposed by Katamba (1993) and Bauer (1983) applied. Futhermore, the meanings of new noun lexemes were based on the meaning of words in English Dictionary.

\subsection{Method and Technique of} Presenting Result of Data Analysis

The informal method was used in analyzing the data in this study because the data were described descriptively. Therefore, it just describes the derivational affixes forming noun in the novel. The technique of presenting the data was done by giving morphological description for the processes of derivational affixes found.

\section{Result and Discussion}

\subsection{Preliminary}

The data that had been analyzed were were the noun forming derivational affixes taken from the novel " $A$ Christmas Carol" written by Charles Dickens in 1834. The analysis began with the description about noun and its form in English words. The process and result of the noun forming derivational affixes were shown in the table after each description of affixes. There were two types of derivational affixes found in this novel, namely word class changing affixes and word class maintaining affixes which lead to class-maintaining derivational process. The class-changing derivational process Meanwhile, the class-maintaining derivational process involved affixes that are attached to noun.

\subsection{Word Class Changing Affixes}

These word classes involved affixes that are attached to verb and adjective. The affixes lead to the class-changing derivational process.

\subsubsection{Verb}

This part of the analysis presents some affixes in the data that can be attached to base form with verb as the word class and to produce noun, namely suffix $-e r$ and sufix $-i n g$.

\subsubsection{Suffix $-e r$}

Suffix $-e r$ is commonly attached to a verb in order to form a noun. This suffix means a person or thing that does something or the act of something. For example:

The register of his burial was signed by the clergyman, the clerk, the undertaker, and the chief mourner. (1834:3)

The underlined word mourner, is the example of word that gets the attachment of suffix -er. According to its sentence structure, it is categorized as noun because it acts as the head of a noun phrase.

The new lexeme mourner is a noun which is derived from the verb with the word base mourn. The addition of suffix - er changes the word-class that the base belong to, from a verb into a noun. The derivational process which occurred is class-changing derivation which produces the new lexeme and belongs to different form class from its base.

Suffix - er means a person or thing. Thus, mourner means a person or thing that mourns. Related to the novel, mourner means the person who is sad for someone's death. 
This process is shown below:

\begin{tabular}{l|c|l} 
Base Form & $:$ & Mourn \\
\hline New Lexeme & $:$ & Mourner \\
\hline $\begin{array}{l}\text { Word-Class } \\
\text { Changing }\end{array}$ & $:$ & Verb into noun \\
\hline $\begin{array}{l}\text { Meaning of } \\
\text { New Lexeme }\end{array}$ & $:$ & $\begin{array}{l}\text { The person or } \\
\text { thing that mourns }\end{array}$ \\
\hline $\begin{array}{l}\text { Meaning } \\
\text { Related to the } \\
\text { Novel }\end{array}$ & $:$ & $\begin{array}{l}\text { The person who is } \\
\text { sad for someone's } \\
\text { death }\end{array}$
\end{tabular}

\subsubsection{Suffix -ing}

Suffix -ing can be attached to a verb to form noun. This suffix means the act, state, process, or result of something. For example:

...there would be nothing more remarkable in his taking a stroll at night, in an easterly wind... (1834:4)

The underlined word taking is an example of word that gets the attachments of suffix -ing. According to its sentence structure, it is categorized as noun because there is the determiner his preceding it.

The new lexeme taking is a noun derived from the verb with word base take. The addition of suffix -ing changes the word-class that the base belongs to, from a verb into a noun. The derivational process which occurred is class-changing derivation which produces the new lexeme and belongs to different form class from its base.

Suffix -ing means an act, process or result. Taking means a person or thing that takes. Related to the novel, taking means someone who takes something.

This process is shown below:

\begin{tabular}{l|l|l} 
Base Form & $:$ & Take \\
\hline New Lexeme & $:$ & Taking \\
\hline $\begin{array}{l}\text { Word-Class } \\
\text { Changing }\end{array}$ & $:$ & Verb into noun \\
\hline $\begin{array}{l}\text { Meaning of } \\
\text { New Lexeme }\end{array}$ & $:$ & $\begin{array}{l}\text { The act of a } \\
\text { person or thing } \\
\text { that takes }\end{array}$ \\
\hline $\begin{array}{l}\text { Meaning } \\
\text { Related to the }\end{array}$ & $:$ & $\begin{array}{l}\text { The act of } \\
\text { someone who }\end{array}$
\end{tabular}

Novel | takes

\subsubsection{Adjective}

This part of the analysis presents some affixes in the data that can be attached to base form with adjective as the word class and to produce noun, namely suffix -ity and suffix $-t h$.

\subsubsection{Suffix -ity}

Suffix -ity is commonly attached to an adjective to form a noun. This suffix means the state or condition of something. For example:

Scrooge followed to the window: desperate in his curiosity. (1834:32)

The underlined word curiosity is an example of word that gets the attachment of suffix -ity. The word curiosity is a noun because it is preceded by the determiner his according to its phrase structure.

The new lexeme curiosity is a noun derived from an adjective with the word base curious. The addition of the suffix ity changes the word-class that the base curious belongs to, from an adjective to a noun. The derivational process occurring is class-changing derivation which produces the lexeme curious and belongs to different form class from its base.

The suffix -ity means state. Thus, curiosity means the condition of being curious. Related to the novel, curiosity means the desire to know something.

This process is shown below:

\begin{tabular}{l|l|l} 
Base Form & $:$ & Curious \\
\hline $\begin{array}{l}\text { New } \\
\text { Lexeme }\end{array}$ & $:$ & Curiosity \\
\hline $\begin{array}{l}\text { Word-Class } \\
\text { Changing }\end{array}$ & $:$ & Adjective into noun \\
\hline $\begin{array}{l}\text { Meaning of } \\
\text { New }\end{array}$ & $:$ & $\begin{array}{l}\text { The state of being } \\
\text { curious }\end{array}$ \\
$\begin{array}{l}\text { Lexeme } \\
\text { Meaning } \\
\text { Related to Novel }\end{array}$ & $:$ & $\begin{array}{l}\text { The desire to know } \\
\text { something }\end{array}$
\end{tabular}




\subsubsection{Suffix - th}

Suffix -th is commonly attached to an adjective in order to form a noun. This suffix means the condition of something. For example:

... and means of warmth. (1834:13)

The underlined word warmth is an example of the word that gets the attachment of suffix -th. The word warmth is a noun because it acts as the head of a noun phrase according to its phrase structure.

The new lexeme warmth is a noun derived from an adjective with the word base warm. The addition of suffix -th changes the word-class that the base warm belongs to, from an adjective to a noun. The derivational process occurring is class-changing derivation which produces the lexeme warmth and belongs to different form class from its base.

The suffix -th means condition. Thus, warmth means the condition of being warm. Related to the novel, warmth means kindness or affection.

This process is shown below:

\begin{tabular}{l|l|ll} 
Base Form & $:$ & Warm \\
\hline $\begin{array}{l}\text { New } \\
\text { Lexeme }\end{array}$ & $:$ & Warmth \\
\hline $\begin{array}{l}\text { Word-Class } \\
\text { Changing }\end{array}$ & $:$ & Adjective into noun \\
\hline $\begin{array}{l}\text { Meaning of } \\
\text { New }\end{array}$ & $:$ & $\begin{array}{l}\text { The condition of } \\
\text { Lexeme }\end{array}$ & \\
\hline $\begin{array}{l}\text { Meaning warm } \\
\text { Related to } \\
\text { the Novel }\end{array}$ & $:$ & $\begin{array}{l}\text { Kindness } \\
\text { affection }\end{array}$ & \\
\end{tabular}

\subsection{Word Class Maintaining Affixes}

The class-maintaining derivational process involved affixes that are attached to noun. There is one kind of affixes in the data that can be attached to base form with noun as the word class and to produce noun, namely suffix $-y$.

Suffix $-y$ is sometimes attached to a noun in order to form a new lexeme with the same word-class. This suffix means a person or thing concerned with or characterized by being something. For example:

...to regard a coffin-nail as the deadest piece of ironmongery in the trade. (1834:3)

The underlined word ironmongery is a word that gets the attachment of suffix $-y$. According to the sentence structure, the underlined word is categorized as noun because it acts as the head of the noun phrase.

The new lexeme ironmongery is a noun derived from noun with the word base ironmonger. The addition of suffix $y$ in this case does not change the wordclass that the base belongs to. Thus, the word-class is still the same, from noun to noun. The derivational process occurring is class-maintaining derivation which produces the new lexeme that belongs to the same form classes as its base. The suffix $-y$ means concerned with. Thus, ironmongery means something concerned with an ironmonger. Related to the novel, ironmongery means the merchandise that is sold in an ironmonger's shop, like ironware.

This process is shown below:

\begin{tabular}{l|c|l} 
Base Form & $:$ & Ironmonger \\
\hline New Lexeme & $:$ & Ironmongery \\
\hline $\begin{array}{l}\text { Word-Class } \\
\text { Changing }\end{array}$ & $:$ & Noun into noun \\
\hline $\begin{array}{l}\text { Meaning of } \\
\text { New Lexeme }\end{array}$ & $:$ & $\begin{array}{l}\text { The one or thing } \\
\text { concerned with } \\
\text { ironmonger }\end{array}$ \\
\hline $\begin{array}{l}\text { Meaning } \\
\text { Related to the }\end{array}$ & $: \begin{array}{l}\text { The merchandise } \\
\text { that is sold in an } \\
\text { ironmonger's } \\
\text { shop, like } \\
\text { ironware }\end{array}$
\end{tabular}

\section{Conclusion}

There are some points which can be drawn as the conclusions of the study based on data analyzed about the noun forming derivational affixes found in the novel A Christmas Carol. 
The classes of the base form that were used to produce new noun lexemes in A Christmas Carol novel were verb, adjective and noun with verb as the most used class of the base form. However, there was no adverb found in this process. The derivational processes found were class-changing derivations which produced the new lexemes from verbs and adjectives and class-maintaining derivation which produced the new lexeme from noun.

Types of affixes that were used to produce new noun lexeme in $A$ Christmas Carol novel were only suffixes, namely suffix -al, -er, -ar, -or, ing, -y, -ion, -ation, -ment, -ance, and age which were attached to verb base, suffix -ity, -th, -ness, and -ence which attached to adjective base and suffix $-y$ which attached to noun base. However, there was no prefix found in this process. The addition of suffix -al, -er, -ar, -or, ing, -y, -ion, -ation, -ment, -ance, -age, ity, -th, -ness, and -ence changed the word-class that the base belongs to, from a verb and adjective into a noun. Meanwhile, the addition of suffix $-y$ which was attached to noun did not change the word-class that the base belongs to. Thus, the word-class was still the same, from noun to noun. The suffixes that were attached to verb base had the meanings of action, agent, result, process, and condition. For the ones that were attached to adjective base had the meanings of state or condition. Meanwhile, the suffix attached to noun base had the meaning of state or condition of something. Thus, the derivational processes found in the novel A Christmas Carol are only suffixations.

\section{References}

Bauer, Laurie. 1983. English wordformation. Cambridge: Cambridge University Press.
Dickens, Charles. 1843. A Christmas Carol. London: Chapma and Hall.

Frank, Marcella. 1972. Modern English: A Practical Reference Guide. New Jersey: Prentice Hall Inc.

Katamba, Francis. 1993. Morphology. The Macmillan press: London.

The Free Dictionary by Farlex, in https://www.thefreedictionary.com/

The Importance of Morphology: English Language as a Prime Example, in http://kurdistantribune.com/importan ce-of-morphology-english-languageas-prime-example/. 